\title{
IAMJ
}

INTERNATIONAL AYURVEDIC MEDICAL JOURNAL

\section{MAHA PANCHAGAVYA GHRITA IN APASMARA (EPILEPSY) - A KETOSIS PERSPECTIVE}

\section{Usha K S , Gurdip Singh $^{2}$}

${ }^{1}$ Professor, Deptartment of Swasthavritta \& Yoga, SDM Institute of Ayurveda \& Hospital, Bangalore - 560074, Karnataka, India, ${ }^{2}$ Director, PG and PhD Studies, SDM College of Ayurveda and Hospital, BM Road, Tanniru Halla, Hassan573201, Karnataka, India

Corresponding Author: $\underline{\text { dr.ushaks@gmail.com }}$

\section{https://doi.org/ $10.46607 /$ iamj4508092020}

(Published online: September 2020)

Open Access

(C) International Ayurvedic Medical Journal, India 2020

Article Received: 22/09/2020 - Peer Reviewed: 26/09/2020 - Accepted for Publication: 26/09/2020

\section{Check for updates}

\section{ABSTRACT}

Epileptic seizures are caused due to imbalance in the excitatory and inhibitory neurotransmitters. Serum electrolytes like sodium, potassium and calcium play a key role in maintaining the epileptic threshold. In the quest of effective treatment in epilepsy ketogenic diet has been promising. It is found to increase the inhibitory Gamma amino butyric acid and thus increase the epileptic threshold. In this context Maha Panvhagavya Ghrita recommended in the treatment of Apasmara seems to be the drug of choice.

Keywords: Epileptic threshold, Ketosis, Gamma amino butyric acid (GABA), Maha Panchagavya Ghrita

\section{INTRODUCTION}

Epilepsy is the fourth most common neurological disease. It has the dubious distinction of affecting all the walks of life of an individual suffering from the disease. There is an ambiguity that shrouds the disease regarding aetiology, pathogenesis and the therapy.
Though modern science boasts of many innovations opening new horizons in the field of research, a comprehensive knowledge regarding epilepsy is still in its infancy. There is an urgent need for retrospection and critical self-appraisal that would initiate casting away 
of fragmented approach and adopting an integrated outlook. At this juncture, some of the concepts of Ayurveda regarding Apasmara project views which seem to contradict the presently held opinion. But it has to be borne in mind that these principles have stood the test of time and have offered solace to the ailing mankind through centuries. The ancient insights may have the potential to provide enlightenment and become beacons of light for modern discoveries. Some of the concepts which have currently dawned as accepted facts have striking similarities with those held in Ayurveda. The observation regarding the epileptic potential of every individual varying only in provocation and the concept of epileptic threshold are gaining substantial prominence. These opinions were voiced vociferously by our Acharyas of yore. Apasmara has been described as a disease caused by the imbalance of Rajo (excitatory) and Tamo (inhibitory) Gunas and the management includes Snehapana. Epileptic threshold plays a main role either way in epilepsy. A low epileptic threshold causes seizures and a high epileptic threshold inhibits the onset of seizures ${ }^{1}$. Mahapanchagavya Ghrita may induce an environment which elevates the epileptic threshold.

\section{Ketosis and its effect on serum electrolytes}

Table 1: enumerates the factors which induce and inhibit seizures

\section{Factors which induce seizures ${ }^{2}$}

Increase in excitatory glutamate neurotransmitter Decrease in serum sodium and serum calcium levels Increase in serum potassium levels
Factors which induce ketosis ${ }^{3}$

Increase in inhibitory Gamma amino butyric acid Increase in serum sodium and serum calcium levels Decrease in serum potassium levels
It is known that high level of fat and protein induce ketosis. The ketone bodies, $\beta$ - hydroxybutyrate, acetoacetate and acetone are synthesized and are able to cross the blood- brain barrier to provide an alternative source of energy for the brain ${ }^{4}$
Drug Review: There are 42 drugs used in the preparation of Maha Panchagavya Ghrita in addition to Cow's milk, curds, ghee, urine and dung ${ }^{5}$.

Table 2: Shows the ingredients of Maha Panchagavya Ghrita

\begin{tabular}{|c|c|c|c|c|c|}
\hline SL. No & Kvatha ( decoction) drugs & $S L . N o$ & Kalka ( paste) drugs & Sl No. & Pancha Gavya \\
\hline $1-10$ & $\begin{array}{l}\text { Dashamula - } \\
\text { Agnimantha (Premna mucronata) } \\
\text { Patala (Stereaspermum suaveolens) } \\
\text { Gambhari (Gmelina arborea) } \\
\text { Bilva (Gmelina arborea) } \\
\text { Syonaka (Oroxylum indicum) } \\
\text { Brhati (Solanum indicum) } \\
\text { Kantakari (Solanum xanthocarpum) } \\
\text { Gokshura (Tribulus terestria) } \\
\text { Salaparni (Desmodium gangeticum) } \\
\text { Prsniparni (Uraria picta) }\end{array}$ & 25 & $\begin{array}{l}\text { Bharngi (Clerodendron serra- } \\
\text { tum) }\end{array}$ & 43 & Cow ghee \\
\hline $11-13$ & $\begin{array}{l}\text { Triphala- } \\
\text { Haritaki (Terminalia chebula) } \\
\text { Vibhitaki (Terminalia bellerica) } \\
\text { Amalaki (Embelica officinalis) }\end{array}$ & 26 & Patha (Cyclia peltata) & 44 & Cow milk \\
\hline 14 & Haridra (Curcuma longa) & $27-29$ & $\begin{array}{l}\text { Trikatu- } \\
\text { Pippali (Piper longum) } \\
\text { Shunthi (Zingiber officinalis) } \\
\text { Maricha (Piper nigrum) }\end{array}$ & 45 & Cow curds \\
\hline & Daruharidra (Berberis aristata) & 30 & Trivrut (Operculina turpethum) & 46 & Cow urine \\
\hline
\end{tabular}




\begin{tabular}{|c|c|c|c|c|c|}
\hline \multicolumn{6}{|l|}{15} \\
\hline 16 & Kutaja (Holarrhena antidysentrica) & 31 & Nicula (Baringtonia acutangula) & 47 & Cow dung \\
\hline 17 & Saptaparna(Alstonia scholaris) & 32 & $\begin{array}{l}\text { Gajapippali (Controversial drug. } \\
\text { Pippali was used in its place) }\end{array}$ & & \\
\hline 18 & Apamarga (Achyranthus aspera) & 33 & Adhaki (Cajanus indicus) & & \\
\hline 19 & Nilini (Indigofera tinctoria) & 34 & Murva (Marsdenia tenecessima) & & \\
\hline 20 & Katuki (Picrorhiza kurroa) & 35 & $\begin{array}{l}\text { Danti (Baliospermum monta- } \\
\text { num) }\end{array}$ & & \\
\hline 21 & Aragvadha (Cassia fistula) & 36 & $\begin{array}{l}\text { Bhunimba (Andrographis panic- } \\
\text { ulata) }\end{array}$ & & \\
\hline 22 & Phalgumula (Ficus hispida) & 37 & Chitraka (Plumbago zeylanica) & & \\
\hline 23 & Pushkaramula (Inula racemosa) & $38-39$ & $\begin{array}{l}\text { Sariva Dwaya -Sweta Sariva } \\
\text { (Hemidesmus indicus) } \\
\text { Krisna Sariva (Not available) } \\
\text { Sweta Sariva was used in the } \\
\text { place of Krishna Sariva due to } \\
\text { unavailability }\end{array}$ & & \\
\hline \multirow[t]{3}{*}{24} & Duralabha (Fagonia critica) & 40 & Rohisha (Cymbopogan martini) & & \\
\hline & & 41 & Yavani (Trachyspermum ammi) & & \\
\hline & & 42 & $\begin{array}{l}\text { Madayantika (Lawsonia in- } \\
\text { ermis) }\end{array}$ & & \\
\hline
\end{tabular}

Maha Panchagavya Ghrita may induce ketosis due to the presence of fats in the form of cow's ghee and various amino acids present in the protein content of cow's milk, curds, urine and cow dung. The ketone bodies produced in turn may alter the blood brain barrier properties giving access to the active principles of the Maha
Panchagavya Ghrita to enter the brain. Many a time Shodhana may not be possible in Apasmara. But a look at some of the drugs used in the Maha Panchagavya Ghrita indicate that they belong to the Shodhana group.

Table 3: contains the drugs used in Mahapanchagavya Ghrita which act as emetic or purgative ${ }^{6}$

\begin{tabular}{|l|l|}
\hline Vamaka ( emitic) & Virechaka ( purgative) \\
\hline Kutaja & Katuki \\
\hline Nicula & Aragwadha \\
\hline & Danti \\
\hline & Nilini \\
\hline & Trivrut \\
\hline & Triphala $^{7}$ \\
\hline
\end{tabular}

\section{Mode of action}

Clinical trial with Maha pancha gavye ghrita showed that there was significant increase in serum sodium and serum calcium levels and decrease in serum potassium levels. ${ }^{8}$ Hence these drugs may bring about Shodhana to some extent and maintain the electrolyte balance thus bringing about equilibrium and maintaining a high epileptic threshold ${ }^{9}$
Shodhana which includes Vamana, Virechana induces changes in the serum electrolyte levels. It has been found in previous studies that Vamana and Virechana cause these changes in the serum electrolyte levels though it is insignificant ${ }^{10}$. Virechana caused increase in serum sodium and serum calcium levels and decrease in serum potassium levels ${ }^{11}$. Therefore ketosis combined with change in serum electrolytes may bring 
about a cumulative change. Hence the epileptic threshold is increased.

\section{DISCUSSION}

The paroxysmal epileptic seizures are caused by many triggering factors which bring down the epileptic threshold and cause change in the serum electrolyte levels. The cause of epilepsy has always remained an enigma. Ketogenic diet has been one area where researchers have found hope. Ketosis does not alter serum electrolyte levels passively but offers the brain an alternate fuel for carbohydrates. In clinical practise Snehapana including Mahapancha gavya Ghrita is used extensively in Apasmara in large doses. It induces ketosis because of the presence of fat and amino acids and helps in the elevation of the inhibitory gamma amino butyric acid. The presence of Shodhana ingredients may bring about changes in the serum sodium, serum calcium levels where they are elevated. The level of serum potassium is decreased. The cumulative effect brings about an elevation in the epileptic threshold.

\section{CONCLUSION}

Maha Panchagavya Ghrita brings about ketosis and increases the gamma aminio butyric acid (GABA) inhibitor as well as causes increase in the serum sodium and serum calcium levels and decrease in serum potassium levels. Epileptic threshold may be an environment which is characterized by all these features. Further studies with other Snehas in epilepsy may throw more light on the relation between Apasmara and ketosis.

\section{REFERENCES}

1. Sushruta Samhita Of Suashruta With The Nibanndhasangraha Commentary Of Dalhana And Nyayacandrika Panjika Of Gayadasa On Nidanasthana Edited From $9^{\text {th }}$ Chapter Of Cikitsasthana By Jadavji Trikamji Acharya And The Rest By Narayan Ram. Chaukhambha Orientalia Varanasi ISBN: 978-81-7637-162-9 Reprint Edition: 2014. Page No 800

2. David S Ludwig. The Ketogenic Diet: Evidence Of Optimism But High- Quality Research Needed. Journal Of Nutrition, Volume150, Issue 6, June2020, Pages 13541359

3. Luis Castila- Guerra Et Al. Electrolyte Disturbances And Seizures. Epilepsia 47(12):1990-1998,2006 Blackwell Publishing Inc.@2006 International League Against Epilepsy.
4. 4.Magdalena Dudzinska. Ketogenic Diet In Epilepsy: An Updated Review. Journal Of Epileptology-Volume26, Issue 1-2, 27/8/2018. Pages 27-47

5. Charaka Samhita Of Agnivesa Revised By Charaka And Dridhabala With Ayurveda Dipika Commentary Of Chakrapani Datta, Edited By Yadavji Trikamji Acharya. Chaukhambha Orientalia Varanasi ISBN:978-81-7637133-9 Reprint Edition:2015. Page No 475

6. Dravya Guna Vijnana Vol.2 By P V Sharma. Chaukhambha Bharati Academy Varanasi ISBN:978-9384541-04-0. Reprint Edition:2019. Page No: 126, 426,170,389,419,463,441

7. Bhavaprakasha Nighantu By Bhava Mishra With Commentary By K C Chunekar,Edited By G S Pandey.Chaukambha Bharati Academy Varanasi ISBN:978-81-909872-0-2 Reprint Edition:2015.Verses 42,43. Page No 12

8. Usha K Satyanarayana And Gurdip Singh (2001): A Clinical Study On Apasmara (-Epilepsy) And Its Management With Mahapanchagavya Ghrita MD (Ayu)Dissertation. Gujarat Ayurved University, Jamnagar

9. P B Kadambari Et Al. A Critical Review On The Concept Of Avapeedaka Snehapana, A Special Mode Of Lipid Administration. Journal Of Evidence Based Integrative Medicine. Volume23:1-5 DOI: $10.1177 / 2515690 X 18770631$

10. Megha Et Al. Effect Of Vamana And Virechana Karma On Serum Electrolytes- A Retrospective Study. International Ayurvedic Medical Journal (Online) 2018

11. Rais A, Bhatted S. Clinical Study To Evaluate The Effect Of Virechana Karma On Serum Electrolytes. AYU 2013;34(4)379-382. Doi:10.4103/0974-8520.127719

\section{Source of Support: Nil Conflict of Interest: None Declared}

How to cite this URL: Usha K S \& Gurdip Singh: Maha Panchagavya Ghrita In Apasmara (Epilepsy) - A Ketosis Perspective. International Ayurvedic Medical Journal \{online\} 2020 \{cited September, 2020\} Available from: http://www.iamj.in/posts/images/upload/4569 4572.pdf 